commonest symptoms. Sometimes a "paradoxical dyspepsia" exists, in which solids are more easily swallowed than fluids and no loss of weight occurs.

The causes of eventration of the diaphragm, with or without paralysis, are varied and sometimes serious. They must be systematically considered in each case if errors of diagnosis are to be avoided.

\section{Preserving Blood}

Q. -What methods are available for the preservation of whole blood for long periods? What are the respective merits of such preservation by glycerolization or by the use of liquid nitrogen for rapid cooling?

A. - When blood is to be preserved over a period of years, the temperature of storage must be well below freezing point. Two methods are available to minimize the haemolysis that occurs when blood is frozen. In the first glycerol is added. This enables the blood to be frozen slowly over a.period of hours, and storage for long periods can be effected at $-45^{\circ} \mathrm{C}$. (or lower). The disadvantage of glycerol is that it must be removed from the red cells by washing before transfusion, and this requires a relatively complicated centrifuge. The second method is to freeze the cells down to very low temperatures during a period of a few seconds. using liquid nitrogen or solid carbon dioxide as coolants. The advantage of this method is that the additives needed to minimize haemolysis can be sugars, such as dextrose or lactose, and these need not be removed before transfusion. The disadvantages are that special equipment is needed to carry out the extremely rapid cooling process; that haemolysis cannot be completely prevented; and that the highest storage temperature is $-93^{\circ} \mathrm{C}$.

\section{Effect of Frying on Fats}

Q. -What is the reason for advising patients with a peptic ulcer to avoid fried foods? What is the difference in these cases between fried and grilled foods, which are often permitted?

A.- Heating fats, as in frying, causes chemical changes that are greater the higher the temperature. Ordinary frying may reach a temperature of only about $210^{\circ} \mathrm{C}$., but if a lead pellet is put in the pan it will be found that it is not difficult to melt it $\left(327^{\circ} \mathrm{C}\right.$.). At about $250^{\circ} \mathrm{C}$. fats tend to polymerize, with consequent loss of digestibility. Unsaturated fatty acids may also be destroyed, and irritant substances such as acrolein may be formed. Grilling is unlikely to form these. Undigestible and irritant substances are, of course, deleterious in peptic ulcer.

\section{Second Confinement at 31}

Q.-A woman had her first pregnancy 10 years ago at the age of 21. She is now aged 31, married again, and is having her second baby. Should she be treated as an elderly primigravida and arrangements for hospital confinement be made? Her first confinement was quite normal.

A.- The hazards to mother and baby in this second pregnancy are much less than if it were a first pregnancy at the age of 31. Nevertheless, the Ministry of Health report, "Confidential Enquiries into Maternal Deaths in England and Wales, 1955-7," ${ }^{1}$ showed that the maternal mortality rate starts to increase after the age of 30 , regardless of parity. Consequently some hospital maternity units with sufficient beds to cope with more than all priority cases have now added "age over 30 " or "age over 35 " to their list of priority classes. If this happy state of affairs does not apply at the local obstetric unit, then this patient might be best seen and her condition assessed by the unit obstetrician now, and again at the 37th-38th week of pregnancy.

REFERENCE

1 Report on Confidential Enquiries Into Maternal Deaths in England and Wales, 1955-57, 1960. Reports on Public Health and Medical Subjects, No. 103. H.M.S.O., London.

\section{E.C.T. and Epilepsy}

Q.-Does E.C.T. ever give rise to epilepsy? I have seen a woman aged 30 with a history of two definite grand-mal attacks recently, but with no previous history or family history of epilepsy. She had E.C.T. five or six years ago.

A.-E.C.T. very rarely gives rise to epileptic attacks, and then usually in obvious association with neurological signs and symptoms that suggest a complication, such as cerebral haemorrhage. It seems unlikely that the E.C.T. has anything to do with the attacks in this patient, and she deserves the usual full investigation for a case of late onset epilepsy.

\section{NOTES AND COMMENTS}

Withdrawing C.S.F. from Spitz-Holter Valves.-Drs. R. G. Grainger and J. Lorber (Sheffield) write: We should like to comment on the answer ("Any Questions ?" June 3, p. 1622) of your expert on the withdrawal of C.S.F. from the lateral cerebral ventricle in children with hydrocephalus being treated by a SpitzHolter valve. We readily agree that there may be no alternative to the puncture of the lateral ventricle, but we wish to emphasize a complication of ventricular puncture which appears to be little appreciated. We have found that there frequently occurs in these children a large cystic hemispherical cavity extending from the site of the ventricular puncture into the surrounding grey matter. A cavity as large as 22 by 22 by $22 \mathrm{~mm}$. has been seen after a single ependymal puncture in a hydrocephalic infant. Ventriculograms of some of these children were presented to the Paediatric Section of the Royal Society of Medicine on June 10 and a large series is to be reported elsewhere (Symposium Neuroradiologicum, Rome, 1961). Since ventricular puncture in hydrocephalic infants. frequently produces a considerable amount of cerebral cavitation, these punctures should be performed as infrequently and with as atraumatic a technique as possible.

Test for Pregnancy.-Dr. M. E. Deursch (Becton, Dickinson and Co., Englewood Cliffs, N.J., U.S.A.) writes: The question in your issue of May 27 concerning use of Lugol's iodine in testing for pregnancy ("Any Questions?" p. 1556) probably referred to the test described by Nicholas Misischia ${ }^{1}$ or to the observations of W. Radetsky, ${ }^{2}$ to which Misischia refers. As a rationale for the test, Misischia suggests that a mixture of epinephrine and norepinephrine is secreted during pregnancy and that this mixture reacts with iodine. He cites Radetsky as being able to reproduce with prolan or corpus luteum the colour produced in this test, but reports inability to get this colour with a variety of gonadotrophic hormones. The accuracy reported by Misischia is $92.4 \%$.

OUR EXPERT replies: I am grateful to Dr. Deutsch for drawing attention to this reference, of which $I$ was previously unaware.

\section{REFERENCES}

1 Misischia, N., J. int. Coll. Surg., 1958, 29, 179.

Correction.-We regret that, in a letter by Dr. David G. Illingworth (July 8, p. 108), the orthotolidine tablet test for occult blood was wrongly called the orthotoluidine tablet test.

\section{Collected Articles from the "British Medical Journal "}

The following books are available through booksellers or from the Publishing Manager, B.M.A. House. Prices, which include postage, are now the same for both inland and overseas. Refresher Course for General Practitioners, Volume 3 (26s. 9d.). Any Questions?, Volume 3 (8s. 3d.).

All communications with regard to editorial business should be addressed to THE EDITOR BRTTSH MEDICAL JOURNAL B.M.A. HOUSE, TAVISTOCK Aitiology, Westcent London. ORIGINAL ARTICLES AND LETTERS forwarded for publication are understood to be offered to the Britlsh Medical Journal alone unless the contrary be stated.

Authors desiring REPRINTS should communicate with the Publishing Manager, B.M.A. House, Tavistock Square, W.C.1, on receipt of proofs Authors overseas should indicate on MSS, if reprints are required, as proofs are not sent abroad.

ADVERTISEMENTS should be addressed to the Advertisement Director, B.M.A. House, Tavistock Square, London W.C.1 (hours 9 a.m. to 5 p.m.). TELEPHONE: EUSTON 4499. TELEGRAMS: Britmedads, Westcent, London.

MEMBERS' SUBSCRIPTIONS should be sent to the SECRETARY of the Association. TElePHONE: EUSTON 4499. TELEGAMS: Medisecra, Westcent, Lundon.

B.M.A. Scotrish OFFICE: 7 Drumsheugh Gardens, Edinburgh. 